\title{
Notary Legal Remedies as Inside Authorities Registration and Registration of Commanditaire Vennootschap through the Administration System of Business Agencies
}

\author{
Masykur $^{1}$, Azhari Yahya ${ }^{2}$, Dahlan $^{3}$ \\ 1,2,3 Universitas Syiah Kuala, Indonesia \\ Masykur06@mhs.unsyiah.ac.id,Azhari.yahya@unsyiah.ac.id,dahlanalifh@gmail.com
}

\begin{abstract}
This study aims to explain the limits and responsibilities of the position carried out by the notary in registration of Commanditaire Vennootschap (CV) online through the business entity administration system. The research method used in this research is normative juridical using a statutory and conceptual approach. The collection of research materials is carried out by examining library materials or secondary data consisting of primary legal materials, secondary legal materials and tertiary legal materials. The results showed that the notary was only authorized and responsible for the creation of the deed of CV. Notary cannot receive power of attorney because it contradicts the UUJN which has been stipulated authority and responsibility attached to the position of a Notary. With the enactment of the Regulation of the Minister of Law and Human Rights of the Republic of Indonesia Number 17 of 2018. Registration of CV which was previously in the District Court is delegated to the Ministry of Law and Human Rights through the online system. The entire Notary is acting as an Authorized Officer not as an authorized official, there is a prosecution of an error in the registration process, then the Notary can indirectly be presented in the trial at the Court but it must be with the permission of the Notary Honorary Council. Thus the Notary can refuse to accept power over online CV registration via $S A B U$, because in carrying out such registration a Notary must position himself as a person not as a public official. This is because it is not regulated in Law Number 30 of 2004 concerning the Position of Notary Public.
\end{abstract}

Keywords

notary legal remedies, registration; business agencies, administration system

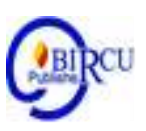

\section{Introduction}

Commanditaire Vennootschap is established with easier terms and procedures, which requires a minimum of two people consisting of one active shareholder and one passive shareholder, using a notary deed. Regarding the establishment of a Commanditaire Vennootschap with a notary deed is regulated in Article 22 of the Commercial Code, which states that "firm companies must be established with an authentic deed, without the possibility of being challenged by a third party, if the deed does not exist". This allowed limited partnership to be established without notary deed. However, in practice, business actors prefer to establish limited partnership with authentic deeds because they relate to evidentiary issues.

After the deed of establishment is drawn up, it is an obligatory to register at the office of the Registrar of the District Court where the Company is domiciled as stated in the provisions of Article 23 of the KUHD, saying that "the company companies are 
required to register the deed in the register provided for that at the registrar's office of District Court, the jurisdiction of the company 's domicile.

Furthermore, there is a requirement to announce excerpts of the act in an official newspaper that the CV has been established and established with an authentic deed as referred to in Article 28 of the KUHD. In practice the deed of establishment of CV is limited to being registered at the Registrar's Office of the local District Court, whereas announcements in official newspapers are rarely made, however the CV can carry out and or carry out business activities, even though in law it is expressly obliged to be announced in an official newspaper.

Regarding the necessity of registering $\mathrm{CV}$ and announcing excerpts of the act which can have legal consequences for the position of $\mathrm{CV}$ and the company itself, the explanation of this matter is confirmed in Article 29 of KUHD "As long as registration and announcement has not occurred, the firm's company to third parties is considered a company general for all affairs, is deemed established for an indefinite period of time and it is considered that no participant is prohibited from exercising the right to act and sign for the firm.

The Government of the Republic of Indonesia has promulgated the Regulation of the Minister of Law and Human Rights Number 17 of 2018 concerning the Registration of Limited Partnership, Firma Fellowship, and Civil Alliance (Permenkumham Number 17 of 2018). Since then, CV registration has changed from a manual registration system to an electronic or online registration and registration system in the Business Entity Administration System (SABU). Previously, the registration of CVs, Firms, and Civil Partnerships was carried out in The Registrar's Office of the District Court as stipulated in Article 23 KUHD.

The purpose of establishing Permenkumham No.17 of 2018, is to simplify and tidy up CV, Firm, and Civil Guild registration data collected through the Business Entity Administration System (SABU). Another goal is expected to do registration or ratification more efficiently and effectively.

In Permenkumham Number 17 of 2018, it is explained that the Application for registration of the establishment of CV, Firm, and Civil Alliance is submitted by the Applicant to the Minister, as stated in Article 1 point 6, namely that the Petitioner is a joint founder or allies who will register CV, Firma, and the Civil Association which authorizes Notaries to submit applications through the Business Entity Administration System (SABU).

Article 5 paragraph (1) Permenkumham Number 17 of 2018 states that an applicant has the right to apply for the name of CV, Firm, and Civil Alliance through SABU. Furthermore, Article 5 paragraph (2) mentions several requirements for the name of CV, Firm, and Civil Alliance, including the name of the Guild "has not been used legally by CV, Firm, and other Civil Partnerships in the Business Entity Administration System".

In Article 8 Permenkumham Number 17 of 2018, the consequences of not fulfilling the terms of the name of the Alliance are stated. as regulated in Article 5, the "Minister can electronically reject the name of CV, Firm, and Civil Guild". This means that if the applicant submitting a name for a business entity is found to have been used legally by another business entity in SABU, then there are legal consequences in the filing of the name that can be rejected by the Minister.

In the implementation of registration and registration of $\mathrm{CV}$ which is done online on lineIt is also possible for problems that cause legal consequences, such as errors in typing the CV name in the system, typing errors in the Identity Number (NIK) and names of the participants, as well as other errors that occur due to the incompatibility of the data on the 
$\mathrm{CV}$ deed with those entered in system. Therefore, the facts presented above will cause losses to business actors, such as not being able to access online licensing registration, and may hinder the business activities of the CV.

The connection in $\mathrm{CV}$ registration through the Business Entity Administration System (SABU) is the granting of power by the joint founder or allies to the Notary. Granting power of attorney (lastgeving) is regulated in book III Chapter XVI starting from Article 1792 to Article 1819 of the Civil Code (KUHPerdata). The meaning of granting power in Article 1792 of the Civil Code is an agreement which contains the granting of power to another person who receives it to carry out something on behalf of the person who gives the power. From this understanding, it can be interpreted that in the case of granting power, there are two parties, namely the power of attorney and the recipient of power who is given an order to do something for and on behalf of the power provider.

\section{Review of Literatures}

Notary comes from the word "nota literaria", which is a written sign or character used to write down or describe a sentence conveyed by a speaker. The sign or character in question is a sign used in shorthand (stenographies). Initially, the position of a Notary was essentially a public official (private notary) assigned by the general power to serve the needs of the community for authentic evidence that provides certainty for the relationship between Civil Law, so as long as authentic evidence remains required by the state legal system, the existence of a Notary will still be required. in the middle of society. ${ }^{1}$

According to Indonesian Dictionary, a notary means a person who gets power from the government by appointment (in this case the Department of Law and Human Rights) to ratify and witness various letters of agreement, wills, deeds, and so on. Article 1 number 1 of Law Number 2 of 2014 concerning Amendments to Law Number 30 of 2004 concerning Notary Office determines that "Notaries are public officials who have the authority to make authentic deeds and other powers as referred to in this law". ${ }^{2}$

Meanwhile, the explanation of notary act called UUJN states that: "Notary is a public official who is authorized to make authentic deeds as long as the making of certain authentic deeds is not reserved for other public officials". The definition given by the UUJN refers to the duties and authorities carried out by the notary. This means that the Notary has the duty as a public official and has the authority to make authentic deeds and other powers regulated by the Law on Notary Position.

The definition given by the UUJN refers to the duties and authorities carried out by the notary. This means that the Notary has the task of being a public official and has the authority to make authentic deeds and other powers regulated by the Law on Notary Position. The 1860 Notary Office (PJN) stipulates that the work of "Notary is an official job (ambtelijke verrichtingen) and the only general official authorized to make an authentic deed, as long as there is no regulation that gives similar authority to other officials". ${ }^{3}$

${ }^{1}$ G.H.S Lumban Tobing, Notaris Reglement, Jakarta: Aditya Bakti Press, 1999, page. 41

${ }^{2}$ Tim Penyusun Kamus Pusat Pembinaan dan Pengembangan Bahasa, 1990, Kamus Besar Bahasa Indonesia, Jakarta: Balai Pustaka,1990, page. 618.

${ }^{3}$ C.S.T Kansil dan Christine S.T. Kansil, Pokok-Pokok Etika Profesi Hukum, Jakarta: Pradnya Paramita, 2003, page. 87. 


\section{Discussion}

Public services have a "multi-dimensional" aspect. Public services can not only be approached from one aspect, for example from the legal aspect or the political aspect. But it also covers economic aspects and socio-cultural aspects in an integrative way. Public service in a legal perspective is a public service which is an obligation given by the constitution or laws and regulations to the government, in this case state administrators, to fulfill the basic rights of citizens or residents for a service. ${ }^{4}$

Article 1 point 1 of the Law on Public Services is defined as an activity or series of activities in the framework of fulfilling service needs in accordance with statutory regulations for every citizen and resident of goods, services and / or administrative services provided by service providers public. ${ }^{5}$

One form of reference in the administration of the State which is carried out by government officials by issuing a legal product that has regulatory and binding characteristics in general. Any legal product issued by government officials whose content material must not conflict with the content contained in the 1945 Constitution and the prevailing laws and regulations in Indonesia, so that legal certainty can be applied. This is also contained in Article 7 of Law Number 12 Year 2011 concerning the Formation of Legislation, in the explanation of Article 7 paragraph (2) the hierarchy is the separation of each type of statutory regulation based on the principle that the lower laws and regulations. must not conflict with higher regulations. ${ }^{6}$

Based on the normative provisions stipulated in the laws and regulations, the application of positive law must also comply with certain principles, which are based on constitutional politics and the provisions of the 1945 Constitution as well as general principles that apply in statutory regulations. the principle of leveling of statutory regulations (lex superior derogate legi inferior), if we refer to these provisions, a lower regulation must not conflict with higher laws and regulations, this provision can be overridden except in more statutory regulations. The higher level regulates matters which are stipulated by law to be the authority of the lower statutory regulations. ${ }^{7}$

The issuance of Permenkumham Number 17 of 2018 implementing regulations related to everything related to the Vennootschap Comanditaire (CV) is regulated in Articles 16-35 of the KUHD, the establishment of CV in this KUHD is established based on an agreement between someone or more who has common goals. Basically, the establishment, which is established on the basis of an agreement between 2 (two) or more people, which is stated in the form of an authentic deed or made before an authorized official, in this case a Notary. ${ }^{8}$ This has been done so that the player in the CV must immediately register at the District Court to get its legality, CV registration is registered at the District Court in accordance with the area where the CV is located. While the registration system regulated in the a quo Permenkumham is different from the registration system regulated in the KUHD, the procedures for application and registration will be described by the author below: ${ }^{9}$

\footnotetext{
${ }^{4}$ Sirajuddin, Hukum Pelayanan Publik "Berbasis Partisipasi \& Keterbukaan Informasi", Malang: Setara Press, 2012, page. 12 .

${ }_{6}^{5}$ Pasal 1 ayat (1) Undang-undang Republik Indonesia Nomor 25 Tahun 2009 Tentang Pelayanan Publik.

${ }^{6}$ Pasal 7 ayat (2) Undang-undang Nomor 12 Tahun 2011 Tentang Pembentukan Peraturan Perundangundangan.

${ }^{7}$ Bagir Manan, Hukum Positif Indonesia "Suatu Kajian Teoritik, Yogyakarta: FH UII Press, 2004, page. 56.

${ }^{8}$ Ibid, page. 56

${ }^{9}$ Pasal 3 Peraturan Menteri Hukum dan Hak Asasi Manusia Republik Indonesia Nomor 17 Tahun 2018

Tentang Pendaftaran Persekutuan Komanditer, Persekutuan Firma, dan Persekutuan Perdata.
} 


\subsection{Role of Notary Position in SABU}

According to Rudhi Prasetya, "A partnership company can run its business in the economic sector, for example industry, trade and services. The form of the partnership company can be in the form of Firm (Fa) and the Limited Partnership or Comanditaire Vennootschap which is often abbreviated as CV ". In a limited partnership or Commanditaire Vennootschap or limited partnership, hereinafter referred to as $\mathrm{CV}$, there are one or several people as limited partners. Limited allies only hand over money, goods or labor to $\mathrm{CV}$ as income and they do not interfere in the management and control of the partnership. ${ }^{10}$

The legal status of a limited partnership can be likened to a person who lends or invests capital in a company and it is hoped that the investment will result in the profit from the capital that is lent or invested. Flexibility in the establishment and management of $\mathrm{CV}$, in practice has led to developments in the legal position and capital aspects of CV.

Regarding the capital aspect, if CV's capital is deemed insufficient, then the CV which was originally on behalf of an individual can be developed into a CV (consisting of Komanditer Allies and Complementary Allies) which is divided into shares. In this way, $\mathrm{CV}$ can raise larger funds to finance its business activities. The deed of establishment that is registered at the Registrar's Office of the District Court where the limited partnership is domiciled. After that, the summary deed of establishment of the partnership will be announced in the Supplement to the State Gazette of the Republic of Indonesia. ${ }^{11}$

The minimum substance of the articles of association of a Limited Liability Company is regulated in Article 15 paragraph (1) of Law Number 40 of 2007 concerning Limited Liability Companies. However, the certainty and legal strength of the shareholders in $\mathrm{CV}$ for shares is not yet clear as is the case with Limited Company (PT). Article 19 of the Commercial Code related to the definition of CV normatively only states that "an alliance by borrowing money or also known as a limited partnership, is held between an ally or more who is personally responsible and for all with one or more money borrowers". In other words, $\mathrm{CV}$ regulation is generally regulated in the Commercial Code in Article 19 to Article 23 of the Commercial Code. However, the arrangement with the pattern of lending money in the form of shares or other forms in a $\mathrm{CV}$, has not been specifically regulated.

This means that here there is no normative regulation regarding $\mathrm{CV}$ regulation on shares. Based on this, it is clear that there is a norm vacuum (rechtsvacuum) on the existence of shares in a CV. This issue also affects the notary's authority in assisting allies both at the time of making the deed of establishment of CV and the substance of its articles of association. In Article 15 paragraph (1) of Law Number 2 of 2014 concerning amendments to Law Number 30 of 2004 concerning the Position of Notary Public (UUJN) only stipulates that the authority of a Notary is very general. ${ }^{12}$

These provisions stipulate as follows: "Notary is authorized to make authentic deeds regarding all actions, agreements and provisions required by laws and regulations and / or by those with an interest to be stated in an authentic deed, guarantees the certainty of the deed making date, keeps deeds, giving grosse, copies and excerpts of deeds, all of that as long as the making of the deeds is not assigned or excluded to other officials stipulated by law. ${ }^{13}$

\footnotetext{
${ }^{10}$ Rudhi Prasetya, Maatschap Firma Dan Persekutuan Komanditer, Jakarta: Citra Aditya Bakti, 2002, page. 29.

11 Ibid, page. 29.

12 Ibid, page. 30 .

${ }^{13}$ Ibid, page. 30 .
} 
Anyone who wants to set up a company, Akta is the first step to the legality process. Any Business Entity needs a deed to certify the business entity they wish to establish. Company Deed and Ratification are the basic requirements needed to continue the processing of documents such as NPWP or SKDP. Apart from the above, several things that might be of mutual concern to the Regulation of the Minister of Law and Human Rights Number 17 of 2018 concerning the Registration of Limited Partnerships, Firma Fellowships, and Civil Fellowships, hereinafter referred to as Permenkumham No. 17 2018, namely in Article 5 paragraph (1) Permenkumham No. 17/2018 stipulates that an applicant has the right to apply for the name of the CV association. ${ }^{14}$

Article 5 paragraph (2) Permenkumham No. 17/2018 then regulates several requirements for the name of the Guild, among others, the name of the Guild "has not been used legally by CV, Firma and other Civil Associations in the Business Entity Administration System". Furthermore, Article 8 Permenkumham No. 17/2018 regulates the consequences of not fulfilling the terms of the Guild's name as regulated in Article 5, namely, "The Minister can electronically reject the name of CV, Firma, and Civil Guild". This means that if an applicant submits a name of the Guild which turns out to have been used legally by another Alliance on saturday, then there is a legal consequence that the filing of that name can be rejected by the Minister.

Based on Article 4 Permenkumham No. 17/2018, the application for registration of the association must be preceded by submitting the name of the association. If this Article 4 is linked to Article 8 of the Permenkumham, then the question that may arise is if the application for registration of establishment must be preceded by submission of the name of the Guild, whether the applicant whose name has been rejected by the Minister can proceed to the application stage for registration of the establishment of the Guild and whether it can be Interpret that receiving the application for the use of the Guild's name is a "condition" for an applicant to be able to proceed to the application stage for registration of establishment. ${ }^{15}$

Arrangements for the establishment of the Civil Society, Firm and CV in BW and the Indonesian Commercial Code (KUHDagang), that the process of establishing the Guild according to BW and KUHDagang is relatively "easier" because there is no obligation to "order names", as regulated in the Permenkumham Number 17 of $2018 .{ }^{16}$

Basically, the establishment of the Firm Association was still established based on an agreement between allies (Article 15 KUHDagang jo. Article 1320 BW). However, Article 22 of the KUHDagang requires the formality of establishing a firm partnership to be established with an authentic deed, although this requirement is "weakened" by Article 22 of the KUHDagang itself which states that the absence of an authentic deed cannot be put forward for the loss of a third party. From the formulation of Article 22 of the Commercial Code, many people interpret that the existence of an authentic deed is not an absolute requirement for the establishment of a firm association so that the authentic deed is actually only for the sake of proof (Article $1902 \mathrm{BW}){ }^{17}$

Referring to the arrangement for the establishment of the Firma Fellowship above, if compared, Article 4 Permenkumham Number 17 of 2018 stipulates that each application

\footnotetext{
${ }^{14}$ Arman Lany, 'Kepastian Dan Perlindungan Hukum Dalam Pendirian Perseroan Terbatas Melalui Sistem Administrasi Badan Hukum Menurut Undang-Undang Nomor 40 Tahun 2007 Tentang Perseroan Terbatas', Padjadjaran Jurnal Ilmu Hukum (Journal of Law), 2018, page. 291-312.

${ }^{15}$ Fina Rizki Utami, Muhammad Syaifuddin dan Achmad Syarifuddin, 'Perubahan Status Persekutuan Komanditer (Commanditaire Vennotschaap/CV) Menjadi Perseroan Terbatas (PT)', Repertorium: Jurnal Ilmiah Hukum Kenotariatan, 7.2 (2019), page. 161.

${ }^{16}$ Ibid. page. 161.

${ }^{17} \mathrm{Ibid}$, page. 161 .
} 
for registration for the establishment of the Guild must be preceded by an application for the use of a name, while the KUHDagang does not provide regulations regarding the use of the firm's partnership name and CV so that firm allies are free. determine the name of the partnership (also applies to civil partnerships and CVs). It's just that, in Article 16 of the Commercial Code, it is stated that the firm association runs its business under one common name. Regarding how the joint name of the Firm, KUHDagang does not provide any arrangements.

The interesting thing about this is that there is a conflict between the Commercial Code and the Minister of Law and Human Rights Regulation Number 17 of 2018, where Article 23 of the Commercial Code says that registration is submitted through the Registrar's Office of the District Court of the jurisdiction of the company. Meanwhile in Permenkumham No. 17 of 2018 in Article 3 Paragraph (2) states that registration is submitted through the Business Entity Administration System (SABU). Seeing this, the issue of the existence and strength of binding laws and regulations as stipulated in Article 8 paragraph (1) of Law no. 12/2011, including Ministerial Regulation, Article 8 paragraph (2) of Law no. 12/2011 does not only regulate the existence of laws and regulations on the basis of delegation (regulations that are ordered by a higher level of legislation). Article 8 paragraph (2) Law no. 12 of 2011 concerning the Formation of Legislation also confirms the existence of laws and regulations "which are formed on the basis of authority".

\section{Conclusion}

The legal remedy of a Notary as a proxy for registration and registration of business entities through the Business Entity Administration System (SABU) which can be taken by a Notary is refusing to sign a power of attorney. This has the potential for an act against the law and is not regulated in the Law on Notary Position (UUJN) and the potential for a lawsuit to occur before the court.

\section{References}

Manan, Bagir. (2004). Hukum Positif Indonesia "Suatu Kajian Teoritik”, Yogyakarta: FH UII Press.

Kansil, C.S.T, Christine S.T. Kansil. (2003). Pokok-Pokok Etika Profesi Hukum, Jakarta: Pradnya Paramita.

Lumban Tobing, G.H.S (1999). Notaris Reglement, Jakarta: Aditya Bakti Press.

Prasetya, Rudhi (2002). Maatschap Firma Dan Persekutuan Komanditer, Jakarta: Citra Aditya Bakti.

Sirajuddin. (2012). Hukum Pelayanan Publik "Berbasis Partisipasi \& Keterbukaan Informasi”, Malang: Setara Press.

Tim Penyusun Kamus Pusat Pembinaan dan Pengembangan Bahasa, Kamus Besar Bahasa Indonesia, Jakarta: Balai Pustaka,1990.

Lany, Arman. 'Kepastian Dan Perlindungan Hukum Dalam Pendirian Perseroan Terbatas Melalui Sistem Administrasi Badan Hukum Menurut Undang-Undang Nomor 40 Tahun 2007 Tentang Perseroan Terbatas', Padjadjaran Jurnal Ilmu Hukum (Journal of Law), 2018, hlm. 291-312.

Utami, Fina Rizki., Muhammad Syaifuddin dan Achmad Syarifuddin, 'Perubahan Status Persekutuan Komanditer (Commanditaire Vennotschaap/Cv) Menjadi Perseroan Terbatas (PT)', Repertorium: Jurnal Ilmiah Hukum Kenotariatan, 7.2 (2019), hal. 161. 
Peraturan Menteri Hukum dan Hak Asasi Manusia Republik Indonesia Nomor 17 Tahun 2018 Tentang Pendaftaran Persekutuan Komanditer, Persekutuan Firma dan Persekutuan Perdata.

Undang-undang Republik Indonesia Nomor 25 Tahun 2009 Tentang Pelayanan Publik.

Undang-undang Nomor 12 Tahun 2011 Tentang Pembentukan Peraturan Perundangundangan.. 